\title{
A Discussion of Administration of Local Public Schools in U.S.
}

\author{
Fang Wang \\ College of Foreign Languages, Changchun University of Science and Technology, Changchun, China \\ Email: harmonywang@163.com
}

Received 27 September 2014; revised 28 October 2014; accepted 7 November 2014

Copyright (C) 2014 by authors and Scientific Research Publishing Inc.

This work is licensed under the Creative Commons Attribution International License (CC BY). http://creativecommons.org/licenses/by/4.0/

c) (i) Open Access

\begin{abstract}
The enriched lifestyle enjoyed by U.S. citizens is a result of free public education. Education has gradually evolved into a very complex process because of the expectations of the American people and because of technological advances. Thus, effective education can occur only within an organization that is capable of analyzing the needs of future generations and that is capable of creating delivery systems that will meet the needs. In this article, the author explored the nature of public school districts and public school management in primary schools and secondary schools in U.S. to shed light on the pros and cons of the educational system.
\end{abstract}

\section{Keywords}

Administration, Public School, Management

\section{The Nature of Public School Districts}

In every organization there is a central issue that is the foundation upon which the organization is built. That issue can be reduced to a major question, "What is the mission of the organization?" To the casual observer, this question might appear easily answered, but in reality, it is the most difficult. The difficulty lies in the fact that "mission" is an organic concept that is subject to periodic change.

For school districts, the obvious answer is to educate children, adolescents, and young people. However, what does "to educate" really mean? Does educate mean providing transportation and food service to children or does it mean just providing classroom instruction in the "basics"? Should statistics be a part of the high school mathematic curriculum? Should foreign languages be taught in elementary school? Obviously, there are no pat answers to these questions. However, mission is the only justifiable reason to create, and maintain public school districts.

Therefore, a school district, as an organization, must devise a process by which its mission is continually un- 
der review for the purposes of refining and defining the nuances of that mission. Mission is put into operation by developing detailed and specific goals that direct the governance and management functions of the school district. For example, a common goal in all districts is to provide a sequential learning experience in grades kindergarten through twelve in order to provide each student with the opportunity to acquire reading and language skills commensurate with each student's ability. A second goal might be to provide each student living over one mile from school with transportation services and pick-up points within one half mile from his or her home. Of course, it is desirable for school board members to enunciate the mission of their school district through policy statements that are readily available to the constituents of the district [1].

\section{The Nature of Public School Management}

For the unknown reason, educators prefer to speak about administration rather than management when referring to the functions and tasks performed by superintendents, central office administrators, and principals [2]. Perhaps educators believe that management as a term is more appropriately applied to business and industry, while administration is better applied to educational enterprise [3]. This treatment will use the terms interchangeably because the current literature tends to blur this distinction.

What is meant by the term "management"? Since the Egyptians built the pyramids, people have attempted to define what it is that someone does who is in command that results in a desired outcome. Well, that theorizing is precisely the definition of management; it is controlled action that leads to a desired outcome.

Management in school districts can be viewed from this same perspective but with a little elaboration. It is controlled action because the mission of a school district can only be achieved through well-conceived action. From the viewpoint of an administrator, controlled action usually takes place in the following sequence: First, a decision must be made by the administrator about what he wants the professional, whom he supervises, to do. Then, he must make a decision about which professionals he wants to perform certain functions and tasks. What's more, the administrator must establish a standard of performance that he wants the professional, whom he supervises, to reach. The desired outcome of management in school districts is to provide educational services to children. This is the imperative of educational administration [4].

\section{Competency Model}

Proper and effective management requires competent administrators. Competency means that an administrator has the knowledge and skills necessary to manage the people and resources to attain a desired outcome. Good intentions and being a successful teacher may not necessarily mean that a person will be a competent administrator.

The knowledge necessary to be an administrator has been interpreted in most states to mean completing a set of courses or a graduate program in educational administration. The coursework usually centers around three areas: management; the supervision of professional personnel; and courses in curriculum development.

To be an effective educational administrator, a person must have the ability to control his or her behavior, to supervise other people, and to manage operational functions.

In the final analysis management is an art. Scientific knowledge is a necessity. Learned skills are necessary. However, no one can be an effective administrator through the application of a set of formula. The art of management is the ability that an administrator possesses to analyze and interpret the variables of a decision and to make that decision because of past personal experience and experience in practicing management. Inherent in the analysis and interpretation of variables is the ability to foresee the various consequences that different decisions will create and to choose the consequence that will produce the most desired effect.

\section{The Dynamics of Leadership}

There are multiple levels and degrees of leadership that a superintendent of schools, a principal, or another administrator can achieve based upon the parameters of his job and his desire to become a "high performer." Leadership in the latter case is not a characteristic to be acquired but rather the outcome or result of performance. A person can become a leader in his or her community because of his or her achievements in serving the community; in like manner, a principal can become a leader in education because of his or her recognized achievement in administration. Thus, an individual's high degree of performance is what gives him or her a position of 
leadership.

The very basic level of leadership is derived from the job position. The superintendent of schools is in a leadership position by reason of his or her authority and responsibility. The decision the superintendent makes can have an effect upon every student in the school district and upon every teacher and staff member. Leaders by reason of high performance are individuals who are easily recognized. They outperform their colleagues because of the way in which they set goals for themselves, the way in which they solve problems, how they manage stress, and how they take risks. Research has proliferated in psychology in the last decade about why some individuals outperform others.

\section{The Organization of the Central Office}

Historically, boards of education have delegated the responsibility for implementing school policies to a chief executive office - the superintendent of schools. Thus, the superintendent assumes full control of all operations. As pupil enrollment increases, however, it usually becomes necessary to develop specialized central office functions.

\subsection{The Superintendent of Schools}

No position within education has received more attention in news media and press over the past decade than the superintendency. "The job is much more political than ever before", appears to be the reason why there is such a tremendous turnover rate among superintendents; the turnover rivals that of losing baseball managers. Declining enrollment, teacher layoffs, dwindling financial resources, labor union strikes, and failing pupil achievement test scores constitute some of the major problems facing contemporary public schools. The individual who is often singled out as contributing to these problems rather than solving them is the superintendent of schools. He becomes the tangible target for hurled criticism when the real culprits are too elusive to be found.

As the chief executive officer of the school board, the superintendent is responsible for the following: 1) Formulating and recommending policies to be adopted by the board of education; 2) Establishing administrative rules and regulations that are necessary to carry out the policy decisions of the board; 3) Preparing and submitting an annual budget to the board of education; 4) Expending the board approved budget in accordance with school board policies; 5) Recommending candidates for employment to the board of education; 6) Formulating and administering a program of supervision for the instructional program. The superintendent of schools is also responsible for assuming a leadership role with other professional educators at the local, state, and national levels. This will help the superintendent to be informed about current issues facing education, which he in turn should communicate to the board of education and the local school community.

This description of the role and function of the superintendent clearly established the significance of his position as the chief executive officer of the school board. He is not by position the head teacher or the lead administrator or the instructional leader of the school district. He is first and foremost the chief executive officer of the board. This does not imply that the superintendent cannot function as an instructional leader or be identified with the teaching and administrative staff. The ideal superintendent fulfills all of these roles.

\subsection{The Administrative Team}

The superintendent of schools is responsible for the overall management of the school district. Obviously, it is impossible for the superintendent to manage all the major functions himself except in the very smallest of school districts. Functions such as personnel management, secondary school management, elementary school management, curriculum services management, and administrative support services management are usually delegated to assistant superintendents in most districts.

These assistant superintendents, along with other administrators, constitute the administrative team. The concept of team management refers to participation of all administrators in setting administrative policy and of translating these policies into administrative strategies. Administrative policies are goals that management believes are necessary to fulfill the mission of the school district as reflected in the board of education policies. Administrative strategies constitute the game plan on how the goals can be achieved. The strategies are implemented through processes and procedures that address daily operations.

Thus, the superintendent conferring with the assistant superintendents at a cabinet meeting about a new board 
of education policy on affirmative action might ask the assistant superintendent for personnel to draft a list of appropriate goals on recruiting minority candidates for job vacancies. At a subsequent cabinet meeting when these goals are presented, each assistant superintendent could discuss how the goals can be achieved in their respective areas of management. The assistant superintendent for personnel would then meet with his staff and discuss how the strategies can be realized. In other words, what procedures can be initiated in the recruitment process to attract minority candidates? Perhaps contacting college and university job placement offices that have a large representation of minorities could be one procedure while a second could be advertising in newspapers of general circulation. Notification of vacancies in all internal divisions of the school district could be a third procedure. The assistant superintendents managing these divisions might have decided at the cabinet meeting that they would encourage minorities working under their supervision to apply for promotions when vacancies occur.

This team management approach is applicable to each level within the school district. An assistant supperintendent should formulate and establish division policies and strategies with his staff members.

The advantages to the tem management approach are obvious. First, team management makes good use of the talent present in all school district. Second, change is more likely to be implemented with minimal resistance if decisions are cooperatively made. Third, all levels within the district are forced to identify administrative policies and strategies that are compatible and have the same ultimate objectives.

\section{Individual School Building Organization}

During the early years of our country's development, one-room school houses were staffed by teachers who were responsible not only for instruction but also for performing all tasks related to maintenance and upkeep of the buildings. This situation gradually changed during the 1800s as education developed into a profession. By the beginning of the 1900s, education has advanced to the point where instructional materials, teaching techniques, and licensing requirements highlighted the expertise of the teacher. One aspect of that expertise is the capability of the teacher to take a body of knowledge and organize it into instructional units or lessons. A second aspect is the skill to present the lessons in such a way that students learn the content.

This specialization of the teacher's role was the catalyst that caused the creation of the modern-day principalship. During the evolutionary period of the teacher's role, many forms appeared as precursors to the present day function of the building principal. As schools expanded and employed more teachers, one was usually chosen as the headmaster or headmistress. This was a little brought over from English and, as the word itself indicates, the head teacher has charge of the school.

\subsection{Elementary Schools}

The pattern of grade level organization could be kindergarten through grade five, through grade six or through grade eight, depending upon the organizational pattern of the secondary school grogram. The curriculum organization could be nongraded or traditional with team teaching or with undivided classroom teacher units. The school building, in like manner, could have an architectural design utilizing the open-space concept or the selfcontained classroom model.

The principal is the administrative executive in the elementary school building. It is his or her responsibility to provide the leadership necessary for the effective execution of the school's mission, which is, of course, to educate the children in his or her school. The primary skill of the principal is to manage the human and material resources available in such a manner that the school's objective is realized. The role of the elementary school principal, therefore, revolves around performing the following tasks: 1) Formulating building level policies to clearly define the duties and responsibilities of the professional staff, classified staff, students, and parents in the school's attendance area; 2) Developing a personnel planning forecast to ensure that the right number of staff members with the most appropriate credentials are available to carry out the mission of the school; 3) Conducting an ongoing projection of pupil enrollment which will be the basis used in personnel planning and budgeting; 4) Developing a building level budget for supplies, materials, and equipment; 5) Initiating an ongoing facility maintenance and operations plan to ensure that the building is energy efficient and in proper condition.

The principal as administrative executive is rather new concept in many school districts but has become a necessity, given the complexity of our contemporary society. Traditionally, the principal evaluated teacher performance and handled chronic pupil disciplinary problems. This concept does not mollify the traditional role of the principal but rather expands the scope of his responsibilities. 


\subsection{Secondary Schools}

The enrollment could be from fifteen hundred to two thousand students. The pattern of grade level organization might be: junior high school (grades 7 - 9) and high school (grades 10 - 12) or middle school (grades 6 - 8) and high school (grades 9 -12). Middle schools have become the subject of much research within the last decade and have proven to be an effective method of organizing the curriculum. Child development theory appears to substantiate that sixth-grade students are closer in maturity to seventh and eighth-grade students than to fifth graders. In like manner, ninth-grade students are closer in maturity to tenth graders than they are to eighth-grade students. The emphasis in middle school, like that in an elementary school, should be on learning as it relates to child development and the acquisition of basic skills, rather than on mastering the rudiments of a subject area.

Junior high schools are structured to provide the student with a transition period to high school and more closely resemble high schools in curriculum and instructional philosophy. It is important for teachers and administrators to guard against making a junior high school into a miniature senior high school. The emphasis should be on preparing the student for his high school experience.

Much of what has been said about the role and function of the building principal, instructional staff, professional support staff, and classified staff can be applied to secondary school personnel. The principal, as the administrative executive of a secondary school is responsible for developing building level policies, for personnel planning, for pupil enrollment projecting, for budget preparation, and for facility management. The major difference is that the secondary school principal usually shares these responsibilities with an administrative team composed of assistant principals who are assigned to specific areas of management. Of course pupil discipline and communicating with parents are the responsibilities of all staff members. Teacher evaluation is a most important responsibility and is such a time-consuming process that most principals divide the number of teachers to be evaluated.

\section{Summary}

Providing educational services has evolved into a complex process because of the expectations of the American people and because of advances in technology. Instruction, as the key component of these educational services, can be effectively provided to children only within an organization charged with the delivery of these services. That organization is the local school district.

Each school district must devise a process by which its mission is continually under review for the purpose of refining and defining the nuances of that mission. This mission is viewed in practice as the detailed and specific goals that direct management functions of the school district. Thus, management may be defined as controlled action that leads to an outcome.

There are multiple levels of leadership that an administrator can attain. The basic level is derived from a person's job position. Successive degrees of leadership are attained because of the level of performance that an individual achieves. Leadership is necessary characteristic of an educational administrator. The individual schools in our contemporary society are composed of an administrative staff, instructional staff, professional support staff, and classified staff. Each of these categories of employees performs a vital service toward the accomplishment of the school's mission—-to educate children and young people.

\section{References}

[1] Peter, D. (1983) Quality Education: The New Growth Area. The Wall Street Journal, 24.

[2] Gorton, R.A. and Kenneth, E.M. (1978) The Senior High School Principal, Volume II: The Effective Principal. National Association of Secondary School Principals, Reston.

[3] Hanson, M.E. (1979) Educational Administration and Organizational Behavior. Allyn and Bacon, Boston.

[4] Rebore, R.W. (1985) Educational Administration: A Management Approach. Prentice-Hall, Upper Saddle River. 
Scientific Research Publishing (SCIRP) is one of the largest Open Access journal publishers. It is currently publishing more than 200 open access, online, peer-reviewed journals covering a wide range of academic disciplines. SCIRP serves the worldwide academic communities and contributes to the progress and application of science with its publication.

Other selected journals from SCIRP are listed as below. Submit your manuscript to us via either submit@scirp.org or Online Submission Portal.
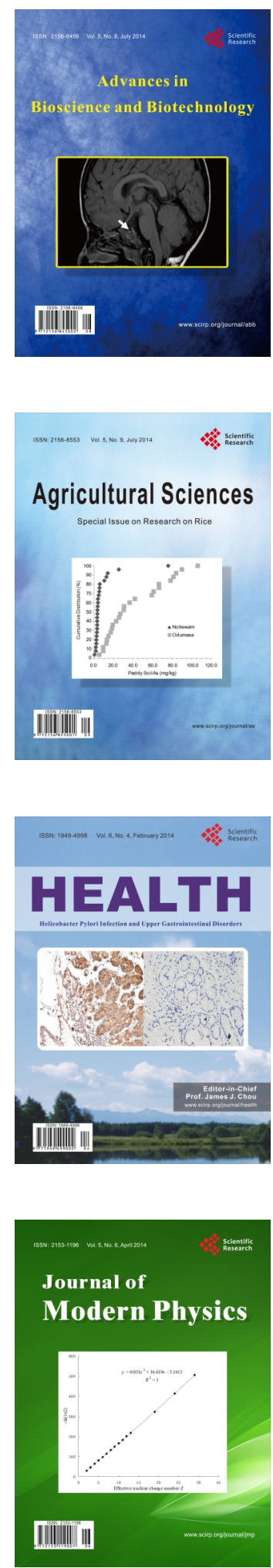
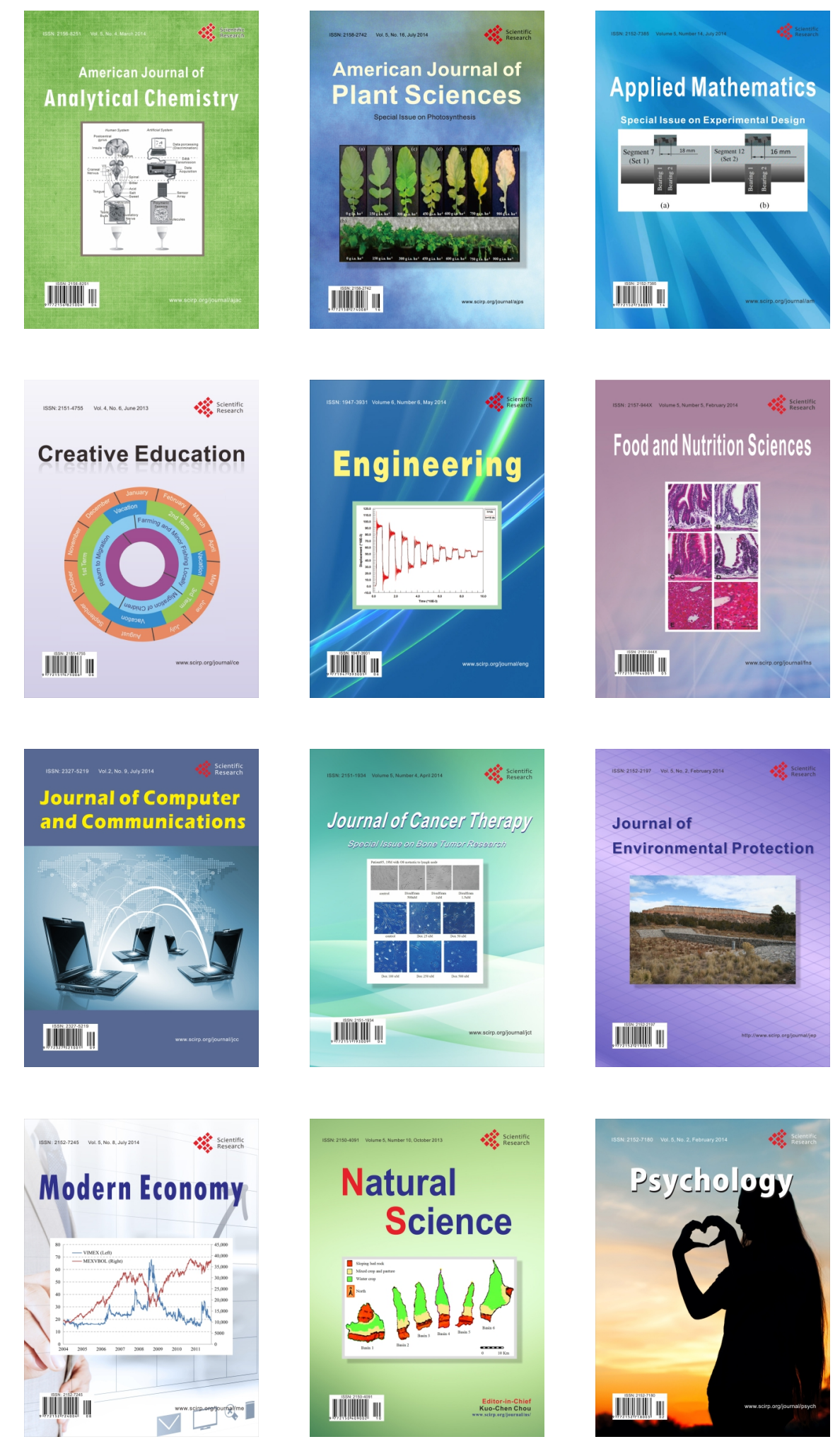